Piotr Józefiak

(Archiwum Uniwersytetu im. Adama Mickiewicza w Poznaniu)

mgr, piotrjozefiak15@gmail.com

\title{
Edukacja akademicka Marii Okońskiej w świetle archiwaliów
}

Przedmiotem niniejszego tekstu jest ukazanie edukacji akademickiej Marii Okońskiej, jednej z najbliższych współpracowniczek prymasa Stefana Wyszyńskiego oraz założycielki Instytutu Świeckiego Pomocnic Maryi Jasnogórskiej Matki Kościoła (obecnie Instytutu Prymasa Wyszyńskiego). Edukacja ta zostanie ukazana $\mathrm{w}$ oparciu o zachowane materiały archiwalne przechowywane $\mathrm{w}$ archiwach uczelni: Uniwersytetu im. Adama Mickiewicza, Katolickiego Uniwersytetu Lubelskiego i Uniwersytetu Warszawskiego. Omówiona w artykule edukacja akademicka Marii Okońskiej pokazuje jej drogę do zdobycia wykształcenia akademickiego, zarówno podczas drugiej wojny światowej, jak i w okresie krótko powojennym. Należy zaznaczyć, iż zachowana dokumentacja stanowi doskonałe źródło wiedzy zarówno co do charakteru zajęć, jak i programu studiów. Ciekawym elementem jest materiał pisarski, na którym sporządzano dokumenty. Niejednokrotnie są to małe karteczki odzyskane z innych dokumentów, np. formularze z okresu okupacji czy międzywojnia. Zachowanie dokumentacji w tej formie świadczy m.in. o problemach, jakie musieli pokonać pracownicy oraz studenci uczelni wyższych, aby odbudować i zorganizować powojenne życie akademickie. Należy podkreślić, iż dokumentacja zachowana $\mathrm{w}$ archiwach uczelnianych, dotycząca okresu studiów, jest idealnym uzupełnieniem życiorysów wielu znanych osobistości, rozpoczynających swoją drogę ku wybitności na uczelniach, których były słuchaczami. Materiały archiwalne obrazujące edukację akademicką Marii Okońskiej zostały uzupełnione wspomnieniami, które zostały opublikowane. Dotyczą one lat 1920-1948. W nich to możemy odnaleźć informacje źródłowe na temat studiów w czasie tajnych kompletów w Warszawie 
oraz przygotowań do obrony pracy magisterskiej i pisania pracy doktorskiej na Katolickim Uniwersytecie Lubelskim ${ }^{1}$.

\section{Maria Okońska - krótka biografia ${ }^{2}$}

Maria Okońska urodziła się 16 grudnia 1920 r. w Warszawie jako córka Ludwika Okońskiego i Marii z Korszonowskich. Ojciec zginął w czasie wojny polsko-bolszewickiej w 1920 r. Posiadała dwoje rodzeństwa, siostrę bliźniaczkę Wandę, która zmarła w wieku trzech lat, oraz brata Włodzimierza, lekarza, który w czasie drugiej wojny światowej wstąpił do zakonu Marianów. Zmarł 3 kwietnia $1986 \mathrm{r}$.

Edukację elementarną Maria Okońska, ze względu na swój stan zdrowia, rozpoczęła w domu. Następnie w 1931 r., po zdaniu egzaminu, rozpoczęła naukę w jednej z najlepszych szkół państwowych w Warszawie: Gimnazjum i Liceum im. Królowej Jadwigi. W szkole tej ukończyła dwie klasy gimnazjum typu starego oraz cztery klasy gimnazjum typu nowego. Ten etap edukacji zakończyła w 1937 r. złożeniem małej matury. Następnie przez dwa lata pobierała naukę w liceum z programem humanistycznym. Świadectwo dojrzałości uzyskała 25 maja 1939 r. Podjęcie studiów dziennych przerwał jej wybuch drugiej wojny światowej. W czasie okupacji kontynuowała naukę na Tajnym Uniwersytecie Ziem Zachodnich i Tajnym Uniwersytecie Warszawskim. Już w czasie okupacji postanowiła założyć ośrodek wychowawczy dla młodzieży żeńskiej - "Miasto Dziewcząt”. Studia łączyła z działalnością apostolską wśród dziewcząt, z grup tych wykrystalizowała się tzw. "Ósemka" - zaczątek istniejącego do dziś Instytutu Prymasa Wyszyńskiego. Decydującym dla rozwoju grupy było spotkanie w 1942 r. Marii Okońskiej z ukrywającym się w Laskach ks. Stefanem Wyszyńskim, który zgodził się objąć grupę swoim kierownictwem duchowym. Wraz z Janiną Michalską i Marią Wantowską brała udział w powstaniu warszawskim, przybierając pseudonim Emanuela. Organizowała modlitwy oraz podtrzymywała na du-

\footnotetext{
${ }^{1}$ M Okońska, Przez Maryję wszystko dla Boga. Wspomnienia 1920-1948, Warszawa 2008.

2 Biogram Marii Okońskiej oparłem na jej opublikowanych wspomnieniach: M. Okońska, Przez Maryje wszystko dla Boga. Wspomnienia 1920-1948, Warszawa 2008; tejże, Wspomnienie $z$ Powstania Warszawskiego, Warszawa 2004; tejże, Z misją do Komańczy, Warszawa 2006; tejże, Stefan Kardynat Wyszyński na co dzień. Świadectwo, Warszawa 2001. Pomocne przy tworzeniu biogramu były również informacje zawarte na stronach internetowych: M. Brzezińska, Maria Okońska - córka duchowa prymasa Wyszyńskiego, https://kobieta.wp.pl/maria-okonska-corkaduchowa-prymasa-wyszynskiego-5982317966279809a (dostęp 4 lipca 2018 r.); Zatożyciele, http://www.instytut-wyszynskiego.pl/index.php/it/historia?showall=1\&limitstart= (dostęp 4 lipca 2018 r.); E. Polak-Pałkiewicz, Jest Bóg i czegóż ci więcej... (śp. Maria Okońska 1920-2013), http:/ / ewapolak-palkiewicz.pl/jest-bog-i-czegoz-ci-wiecej-sp-maria-okonska-1920-2013/ (dostęp 4 lipca 2018 r.).
} 
chu mieszkańców stolicy. Za tę działalność w 2009 r. otrzymała Krzyż Komandorski Orderu Odrodzenia Polski. Po wojnie kontynuowała naukę na Uniwersytecie Poznańskim, Katolickim Uniwersytecie Lubelskim oraz Uniwersytecie Warszawskim. W 1948 r. została aresztowana i więziona przez trzy miesiące przez Służbę Bezpieczeństwa za swoją działalność duszpasterską. Gdy aresztowano Prymasa Wyszyńskiego, organizowała czuwania modlitewne w jego intencji na Jasnej Górze. W momencie złagodzenia warunków więzienia i przeniesienia Prymasa do Komańczy, odwiedzała go wraz Janiną Michalską i Janiną Wantowską. Została jedynym świadkiem składania przez Wyszyńskiego Jasnogórskich Ślubów Narodu w 1956 r. ${ }^{3}$ Po uwolnieniu Prymasa poświęciła się pracy nad realizacją tychże Ślubów w ramach Wielkiej Nowenny ${ }^{4}$. Do śmierci Wyszyńskiego w 1981 r. pracowała w jego sekretariacie $^{5}$. Następnie podjęła działania na rzecz zachowania dziedzictwa zmarłego Prymasa ${ }^{6}$. Zmarła 6 maja 2013 r. w Częstochowie, w domu pamięci Prymasa Stefana Wyszyńskiego. 11 maja 2013 r. została pochowana na Cmentarzu Bródnowskim w Warszawie w grobowcu Instytutu Prymasa Wyszyńskiego.

\section{Studia na Tajnym Uniwersytecie Ziem Zachodnich i Tajnym Uniwersytecie Warszawskim w latach 1940-1944}

Podjęcie studiów bezpośrednio po uzyskaniu świadectwa dojrzałości przerwał Marii Okońskiej wybuch drugiej wojny światowej. Jednak wkrótce w okupowanej Warszawie zostało uruchomione tajne kształcenie uniwersyteckie, którym zajęli się pracownicy Uniwersytetu Warszawskiego, tworząc tajne komplety. Na terenie Generalnej Guberni schronienie znaleźli wysiedleni z Wielkopolski pracownicy Uniwersytetu Poznańskiego, którzy uruchomili Tajny Uniwersytet Ziem Zachodnich. Okońska zapisała się na oba Uniwersytety.

\footnotetext{
${ }^{3}$ P. Raina, Jasnogórskie śluby Narodu Polskiego 1656-1956-1966, Warszawa 2006.

${ }^{4}$ Tamże.

${ }^{5}$ Szerszych informacji na temat pracy Marii Okońskiej i zgromadzenia przez nią założonego dla Prymasa Wyszyńskiego należy szukać w pracy E. Czaczkowskiej, Kardynat Wyszyński, Warszawa 2009, s. 413-424.

${ }^{6}$ Wyrazem tego są publikacje m.in. kazań i przemówień Prymasa Wyszyńskiego redagowanych przez Marię Okońską, Mirosławę Plaskacz, Annę Rastawicką: S. Wyszyński, Nie gaście Ducha ojca Maksymiliana. Wybór przemówień i listów, Niepokalnaów 1996: tegoż, Zapiski milenijne. Wybór z dziennika "Pro memoria” z lat 1965-1967, Warszawa 2001; tegoż, Miłość ma co dzień. Rozważania, Warszawa 2001; tegoż, A byta tam matka..., Warszawa 2001. Do grona redaktorek przy publikacji S. Wyszyńskiego, Kromka chleba. Wybór myśli i aforyzmów z kazań, przemówień i rozważań, Warszawa 2001, dołączył ks. Zdzisław Peszkowski.
} 


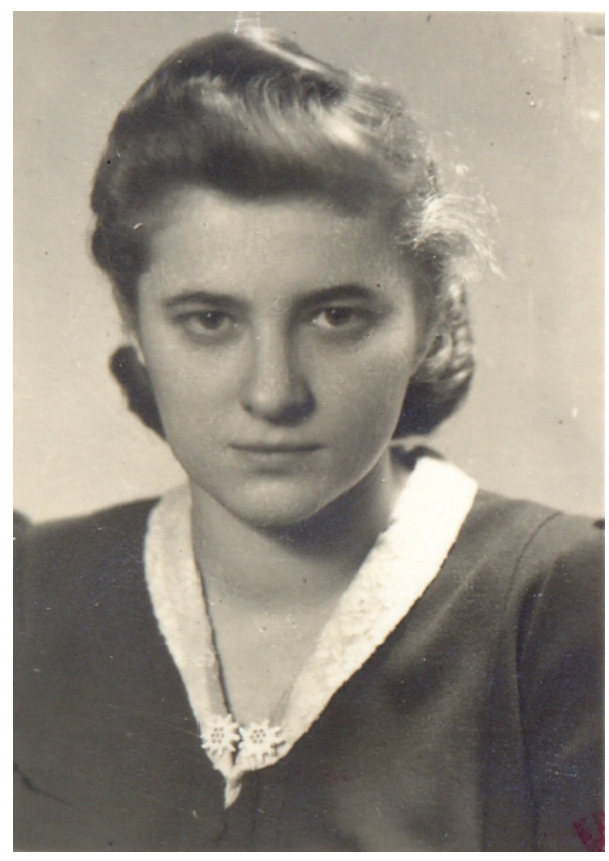

Fot. 1. Maria Okońska jako studentka. Źródło: Archiwum Uniwersytetu Warszawskiego, sygnatura WTK 3142.

W swym wspomnieniach pisała tak: „Ja od roku 1940 chodziłam na Uniwersytet Warszawski, na polonistykę. Od 1941 studiowałam ponadto psychologię na tajnym Uniwersytecie Poznańskim. Był to tak zwany UZZ, Uniwersytet Ziem Zachodnich, który w czasie okupacji działał w Warszawie. Miałam dużo pracy. Ciągnęłam dwa fakultety. Ze względów bezpieczeństwa nie wolno było studiować na dwóch uczelniach, ale jakoś się przemyciłam. Nie mogłam jednak przyznawać się na Warszawskim, że jestem na Poznańskim, i odwrotnie"7.

Dalej wspominała tak: „Zaczęłam od polonistyki, bo myślałam, że ona wypełni moje życie, ale zupełnie mi to nie wystarczyło. Zapragnęłam filozofii i psychologii, jakichś głębszych studiów" ${ }^{\prime \prime}$.

Jedynym potwierdzeniem odbycia konspiracyjnego kształcenia są zaświadczenia wydane i wystawione przez prowadzących wykłady i ćwiczenia, zachowane w zasobie Archiwum Uniwersytetu im. Adama Mickiewicza w Poznaniu.

Pierwszym wykładowcą, który potwierdził kształcenie Okońskiej był doc. dr Marian Wachowski, specjalista z zakresu pedagogiki i oświaty. Na jego zajęciach wysłuchała w ciągu dwóch lat wykłady z historii wychowania i pedagogiki, uczestniczyła również przez rok $\mathrm{w}$ proseminarium pedagogicznym oraz przez rok i dwa trymestry w seminarium pedagogicznym ${ }^{9}$. U tego samego prowadzącego zdała również, z wynikiem bardzo dobrym, egzamin częściowy z historii wychowania, który obejmował starożytność i średniowiecze $^{10}$.

${ }^{7}$ M. Okońska, Przez Maryję wszystko dla Boga, s. 75.

8 Tamże.

${ }^{9}$ Archiwum Uniwersytetu im. Adama Mickiewicza w Poznaniu (dalej AUAM), akta studenckie Marii Okońskiej, sygn. 144/1054 k.11/ dalej cyt. AUAM.

${ }^{10}$ Tamże, k. 12. 
Cztery egzaminy zdawała u rektora Tajnego Uniwersytetu Ziem Zachodnich prof. dr. Ludwika Jaxy-Bykowskiego, który w momencie wznowienia studiów na Uniwersytecie Poznańskim po zakończeniu działań wojennych stał się promotorem napisanej przez nią pracy magisterskiej. Prof. Jaxa-Bykowski należał do wybitnych specjalistów z zakresu pedagogiki i dydaktyki. Trzy z prowadzonych przez niego przedmiotów, obejmujące pedagogikę ogólną, dydaktykę ogólną i organizację szkolnictwa zaliczyła na ocenę bardzo dobrą. Egzamin z pedagogiki eksperymentalnej z psychologią wychowawczą zdała na ocenę dobrą. Jak wynika z treści zaświadczenia, ostatni egzamin miał miejsce 12 czerwca 1944 r. ${ }^{11}$

Natomiast na zajęciach ks. doc. Mieczysława Dybowskiego wysłuchała w ciągu dwóch lat wykładów z psychologii ogólnej, eksperymentalnej psychologii woli oraz psychologii woli dziecka. Przez ten czas była również słuchaczką proseminarium i seminarium psychologicznego. Zajęcia te zakończyła złożeniem egzaminu z psychologii ogólnej z wynikiem dobrym ${ }^{12}$.

Ks. prof. dr Piotr Chojnacki prowadził kurs wykładów z logiki, teorii poznania oraz metodologii ogólnej nauk. Egzamin i zakończenie zajęć miały miejsce w maju $1943 \mathrm{r}$. Egzamin został oceniony przez prowadzącego na ocenę bardzo dobrą ${ }^{13}$.

Ostatnim śladem studiów pedagogicznych jest zaświadczenie wydane przez prof. Władysława Tatarkiewicza, wybitnego specjalisty z zakresu filozofii, historii filozofii i etyki, który w trakcie zajęć przybliżył Okońskiej temat dotyczący historii filozofii. Egzamin $\mathrm{z}$ tego przedmiotu zdała po wojnie $\mathrm{z}$ wynikiem dobrym (lecz przed 12 grudnia 1946 r.), w zakresie, jaki był wymagany do magisterium $\mathrm{z}$ pedagogiki ${ }^{14}$.

Zaświadczenie potwierdzające studia polonistyczne wystawił Marii Okońskiej prof. Julian Krzyżanowski, znawca historii literatury i literatury ludowej, który w czasie drugiej wojny pełnił funkcję kierownika tychże studiów. Z treści tego dokumentu wynika, iż była słuchaczką zwyczajną w latach 1940-1943 oraz że odbyła wszystkie wymagane ćwiczenia seminaryjne. Jeśli chodzi o egzaminy, to złożyła wszystkie wymagane dla słuchaczy I roku oraz część dla roku II ${ }^{15}$. Niestety, na podstawie zaświadczenia nie jesteśmy w stanie stwierdzić, jakich egzaminów brakowało jej do zaliczenia II roku. W momencie wybuchu powstania warszawskiego Okońska przerwała rozpoczęte kształcenie na tajnych kompletach, wznowiła je po zakończeniu działań wojennych.

\footnotetext{
11 Tamże, k. 10.

12 Tamże, k. 7.

13 Tamże, k. 8.

14 Tamże, k. 9.

15 Tamże, k. 13.
} 


\section{Studia na Uniwersytecie Poznańskim w latach 1945-1946}

Bezpośrednio po zakończeniu działań wojennych Maria Okońska postanowiła dokończyć rozpoczęte na Tajnym Uniwersytecie Ziem Zachodnich studia i 26 listopada $1945 \mathrm{r}$. została przyjęta w charakterze słuchacza zwyczajnego na Wydział Humanistyczny Uniwersytetu Poznańskiego. Po podjęciu studiów czyniła starania o zaliczenie odbytych zajęć i egzaminów z czasu drugiej wojny światowej na poczet rozpoczętych studiów. Przedstawiała zaświadczenia prowadzących zajęcia na Tajnym Uniwersytecie Ziem Zachodnich i Tajnym Uniwersytecie Warszawskim, które omówiłem wyżej. Zanim jednak to nastąpiło, zaliczyła dwa trymestry roku akademickim 1945/1946 na Wydziale Humanistycznym. W tym czasie była uczestniczką następujących zajęć - w trymestrze I: Podstawy pedagogiki porównawczej (doc. dr Marian Wachowski), Pedagogika eksperymentalna, Dydaktyka ogólna i eksperymentalna, Prace specjalne (prof. dr Ludwik Jaxa-Bykowski); w trymestrze II: Pedagogika systematyczna, Dydaktyka ogólna i eksperymentalna, Prace specjalne (prof. dr Ludwik Jaxa-Bykowski), Klasa szkolna, Historia wychowania (doc. dr Marian Wachowski) ${ }^{16}$.

Ostatnim etapem studiów było złożenie egzaminu końcowego, który bezpośrednio wiązał się z napisaną pracą magisterską pt. O powołaniu wśród dziewcząt na podstawie ankiety przeprowadzonej w Sodalicji Żeńskiej w Warszawie w latach 1939-1944. Praca ta została napisana pod kierunkiem prof. dr. Ludwika Jaxy-Bykowskiego, recenzentem zaś został doc. dr Marian Wachowski. Egzamin ten składał się z części pisemnej i ustnej. Część pisemna miała miejsce 26 czerwca 1946 r., dotyczyła zadań wychowawczych sodalicji mariańskiej dziewcząt. Egzaminatorem był prof. dr Jaxa-Bykowski. Okońska otrzymała ocenę dobrą. Natomiast 27 czerwca 1946 r. odbył się egzamin ustny z pedagogiki i dydaktyki wraz z dyskusją nad pracą magisterską. W jego trakcie zadano magistrantce pytania: Organizacja pracy klasowej, Środki wychowania religijnego, Stosunek etyki do religii, Wartości wychowawcze Wieczoru trzech Króli Szekspira ${ }^{17}$. Jak wynika z protokołu egzaminu ostatecznego, odpowiadała również na pytania dotyczące terminów związanych z dydaktyką, pojęcie szkoły, programu i metody ${ }^{18}$. Egzamin ustny został oceniony przez komisję na stopień dobry.

Maria Okońska tak pisze $\mathrm{w}$ wspomnieniach o swoim magisterium: „W czerwcu więc wyjechałam do Poznania. Moim głównym profesorem był Ludwik Jaxa-Bykowski. Był mi życzliwy, wiedział o naszej pracy sodalicyjnej,

\footnotetext{
${ }^{16}$ Tamże, k. 1-2. Ostateczne zaliczenie dwóch trymestrów nastąpiło 14 grudnia 1946 r.

17 Tamże, k. 32.

18 Tamże.
} 
okupacyjnej z młodzieżą. Uważał, że młodzież nie tylko powinna się uczyć, ale musi brać udział $w$ walce, rozumiał, że $w$ tej sytuacji nasz czas na naukę był bardzo ograniczony. Zwrócił się do mnie z propozycją napisania pracy kontrolnej przed złożeniem pracy magisterskiej. Wprowadzono mnie do jakiegoś pokoiku, zamknięto i kazano pisać. Dostałam temat: »Metody pracy sodalicyjnej w czasie okupacji«.

W rozmowie powiedziałam Profesorowi, że do września muszę mieć magisterium, bo wybieram się na dalsze studia do Lublina, a w czasie wakacji mam prowadzić obóz akademicki, więc jedyna szansa - zdać egzamin teraz. Profesor zaczął przeglądać moje notatki, które robiłam w Kuźnicach. Był to materiał pozbierany, ale nie do końca opracowany. Przejrzał i powiedział, że uzna ten materiał za pracę magisterską. Uradowana takim obrotem sprawy, umówiłam się na egzamin ustny. Zapytałam co mam na ten egzamin przygotować? Odpowiedział mi: »Jeśli uczyła się Pani przez cztery lata okupacji, nie będzie z tym kłopotu«. Wróciłam do Warszawy z tym, że jeszcze w czerwcu przyjadę na egzamin. [...] Kiedy więc przyjechałam do Poznania z końcem czerwca byłam w wielkim strachu. Prosiłam Profesora, aby podsunął jakąś tezę z tematu, z którego nazajutrz będę odpowiadać. Powiedział: »Proszę pójść do teatru«. Cały dzień spędziłam w bibliotece uniwersyteckiej, dokładnie przeglądając bibliografię z pedagogiki ogólnej i eksperymentalnej, a wieczorem z koleżanką, u której się zatrzymałam poszłam do teatru. Sztuka była świetnie wystawiona: Wieczór Trzech Króli Szekspira. Na drugi dzień stanęłam do egzaminu.

Pierwsze pytanie postawił rektor Jaxa-Bykowski: »Kiedy pani była w teatrze? Proszę powiedzieć, jakie jest pedagogiczne, wychowawcze znaczenie teatru?« Gdy odpowiedziałam, zwrócił się do profesorów: »Chyba panowie nie mają pytań? « Profesor Wachowski powiedział: »Owszem ja mam«. I zadał mi pytanie z pierwszego roku studiów. W pierwszym momencie poczułam w głowię zupełną pustkę, ale potem przypomniał mi się zielony zeszyt, w którym prowadziłam bardzo dokładne notatki z wykładów i definicja, którą wyrecytowałam, jakby z kartki. Profesor zadał drugie pytanie. Znowu odpowiedziałam. Chyba Matka Boża mi pomagała. Ocenę sformułował tak: »Byłoby bardzo dobrze, ale ponieważ nie chodziła pani na seminaria, więc stawiam dobrze plus«. Profesor Tymieniecki nie pytał mnie więc zakończono egzamin i dostałam zaświadczenie, które niestety potem gdzieś zgubiłam"19.

Zatwierdzenie egzaminu ostatecznego miało miejsce 20 grudnia 1946 r., kiedy Rada Wydziału Humanistycznego Uniwersytetu Poznańskiego nadała Marii Okońskiej tytuł magistra filozofii w zakresie pedagogiki ${ }^{20}$.

\footnotetext{
${ }^{19}$ M. Okońska, Przez Maryję wszystko dla Boga, s. 285-287.

${ }^{20}$ AUAM, sygn. 144/1054, k. 36.
} 


\section{Studia na Katolickim Uniwersytecie Lubelskim w latach 1946-1949}

Bezpośrednio po uzyskaniu magisterium Maria Okońska postanowiła kontynuować naukę, chciała przygotować doktorat z psychologii oraz poszerzyć swoją wiedzę z zakresu filozofii. Dlatego w grudniu $1946 \mathrm{r}$. rozpoczęła studia na Katolickim Uniwersytecie Lubelskim w Lublinie. Wybór ten nie był przypadkowy, gdyż w maju 1946 r. Wyszyński został mianowany arcybiskupem lubelskim, ponadto od października $1946 \mathrm{r}$. studia na tej uczelni podjęły członkinie jej zespołu modlitewnego ${ }^{21}$. Z dniem 4 grudnia 1946 r. Okońska została przyjęta na Wydział Filozofii Chrześcijańskiej w charakterze słuchacza zwyczajnego ${ }^{22}$. W roku akademickim 1946/1947 była słuchaczką następujących wykładów, seminariów i ćwiczeń: Wstęp do metafizyki, Historia filozofii średniowiecza, Proseminarium filozoficzne (prowadził je prof. Stefan Świeżawski), Psychologia religii, Psychologia rozwojowa (prowadził te przedmioty ks. prof. Józef Pastuszka), Socjologia (prowadził zajęcia ks. prof. Franciszek Mirek), Zagadnienia wybrane z metafizyki, Seminarium z zagadnieniami metafizyki (prowadził je ks. prof. Stanisław Adamczyk), Historia filozofii nowożytnej (prowadził zajęcia prof. Stefan Harrasek) ${ }^{23}$. W przechowywanej na KUL-u dokumentacji nie zachowały się karty wpisowe na lata akademickie 1947/1948 oraz 1948/1949. Jedyna wzmianka dotycząca przebiegu studiów to informacja na kartach indywidualnych studenta, gdzie określało się przedmiot główny na dany rok akademicki. Maria Okońska w roku akademickim 1947/1948 wybrała psychologię, natomiast w roku akademickim 1948/1949 historię filozofii ${ }^{24}$. Niestety, nie jesteśmy w stanie stwierdzić na podstawie zachowanej dokumentacji, kiedy Maria Okońska zakończyła edukację na Wydziale Filozofii Chrześcijańskiej, gdyż w aktach studenckich brakuje informacji dotyczących rezygnacji, skreślenia czy też ukończenia studiów.

W trakcie swojego pobytu w Lublinie Maria Okońska, prócz pogłębiania wiedzy filozoficznej, postanowiła przygotować dysertację doktorską z zakresu psychologii wychowawczej. Równocześnie z prowadzonymi badaniami naukowymi została mianowana w roku akademickim 1948/1949 na stanowisko starszego asystenta przy Katedrze Psychologii Wydziału Nauk Humanistycznych KUL ${ }^{25}$. Opiekunem naukowym rozprawy został ks. prof.

${ }^{21}$ M. Okońska, Przez Maryję wszystko dla Boga, s. 296-297.

${ }^{22}$ Archiwum Katolickiego Uniwersytetu Lubelskiego w Lublinie (dalej AKUL), akta studenckie Marii Okońskiej, sygn. F 7914.

${ }^{23}$ Tamże.

24 Tamże.

${ }^{25}$ AKUL, akta pracownicze Marii Okońskiej, sygn. A.161. 
Józef Pastuszka, który w grudniu 1948 r. wystawił jej zaświadczenie dotyczące postępów w pisaniu rozprawy. $Z$ jego treści wynika, iż autorka zebrała już materiał z literatury polskiej i zagranicznej oraz przedstawiła plan pracy i dwa rozdziały. Natomiast w jej aktach studenckich zachowało się zaświadczenie utrzymane $\mathrm{w}$ podobnym tonie, lecz $\mathrm{z}$ dokładniejszymi danymi co do tematu rozprawy. Jej wstępny tytuł brzmiał Psychologia dziewcząt w wieku 16-20 lat ${ }^{26}$. Materiał potrzebny do pracy zbierała na postawie ankiet. W swych wspomnieniach Maria Okońska napisała, iż temat jej rozprawy miał nosić tytuł Miłość powołaniem kobiety ${ }^{27}$. Dysertacji doktorskiej nie udało się jej dokończyć. Pracę na stanowisku starszego asystenta zakończyła 31 stycznia 1949 r. na własną prośbę. Jako powód rezygnacji podała nagłą konieczność wyjazdu z Lublina ${ }^{28}$.

\section{Studia na Uniwersytecie Warszawskim w latach 1945-1946 oraz w latach 1949-1952}

W niedługim czasie po zakończeniu edukacji w Lublinie Maria Okońska rozpoczęła studia na Uniwersytecie Warszawskim na Wydziale Teologii Katolickiej. Zanim jednak to nastąpiło, została słuchaczką Wydziału Humanistycznego, w ramach którego postanowiła ukończyć podjęte $\mathrm{w}$ czasie okupacji studia polonistyczne. I tak 2 listopada $1945 \mathrm{r}$. przyjęto ją w poczet studentów tego Wydziału. Prosiła wówczas władze uczelni o zaliczenie jej do grona absolwentów polonistyki. Tak się jednak nie stało. Na karcie wpisowej z Wydziału Humanistycznego widnieje jej uwaga: „na wykłady już nie uczęszczam ponieważ mam zaliczone potrzebne na wydziale polonistyki wykłady i ćwiczenia (seminaria i proseminaria). Brakuje mi kilku egzaminów do ich ukończenia" ${ }^{29}$. Oficjalne zakończenie podjętych po wojnie studiów polonistycznych nastąpiło 21 listopada 1946 r., kiedy Okońska złożyła rezygnację.

Jak wspomniano wcześniej, po powrocie z Lublina do Warszawy Maria Okońska rozpoczęła w roku akademickim 1949/1950 studia na Wydziale Teologii Katolickiej. Jako przedmiot główny wybrała teologię moralną. Ślubowanie złożyła 27 października 1949 r. Będąc słuchaczką tego Wydziału, w roku akademickim 1949/1950 wysłuchała następujących wykładów: Teologia moralna (prowadzący ks. prof. Zygmunt Kozubski), Historia Kościoła (prowadzący ks. prof. Zdzisław Obertyński), Apologetyka (prowadzący ks. prof.

\footnotetext{
${ }^{26}$ AKUL, sygn. F 7914.

${ }^{27}$ M. Okońska, Przez Maryję wszystko dla Boga, s. 299.

${ }^{28}$ AKUL, sygn. A.161.

${ }^{29}$ Archiwum Uniwersytetu Warszawskiego, akta studenckie Marii Okońskiej, sygn. WTK
} 3142. 
Wincenty Kwiatkowski), Egzegeza Nowego Testamentu, Katechetyka (prowadzący ks. prof. Seweryn Kowalski), Egzegeza Starego Testamentu (prowadzący ks. prof. Czesław Jakubiec), Dogmatyka (prowadzący ks. prof. Władysław Rosłan), Liturgika (prowadzący ks. dr Kwieciński), Seminarium katechetyczne (prowadzący ks. Adam Hoffman ${ }^{30}$. Natomiast w następnym roku akademickim 1950/1951 uczęszczała na następujące zajęcia: Ćwiczenia katechetyczne, Katechetyka, Egzegeza Nowego Testamentu (prowadzący ks. prof. Seweryn Kowalski), Apologetyka (prowadzący prof. Wincenty Kwiatkowski), Teologia moralna (prowadzący ks. prof. Stanisław Huet), Historia Kościoła (prowadzący ks. prof. Zdzisław Obertyński), Dogmatyka (prowadzący ks. prof. Władysław Rosłan), Egzegeza Starego Testamentu (prowadzący ks. prof. Czesław Jakubiec).

Od 3 stycznia 1951 r. Marii Okońskiej został udzielony urlop na drugi semestr studiów ze względu na niezaliczenie wysłuchanych wykładów z roku I oraz przedmiotów z III roku studiów ${ }^{31}$. Powodem urlopu były również prace nad doktoratem na Katolickim Uniwersytecie Lubelskim.

W zachowanej dokumentacji studenckiej brakuje jakichkolwiek śladów podjęcia przez Marię Okońską studiów po zakończeniu urlopu, w związku z tym 5 listopada 1952 r. została skreślona z listy studentów.

\section{Podsumowanie}

Głównym celem, jaki przyświecał mi w trakcie pisania tekstu o edukacji akademickiej, było przybliżenie czytelnikowi osoby Marii Okońskiej, którą należy zaliczać do wybitnych absolwentów poznańskiego Uniwersytetu, którzy swą pracę na rzecz społeczności rozpoczynali już w momencie podjęcia nauki.

Należy podkreślić, iż zdobyta w trackie zajęć, wykładów i ćwiczeń wiedza została przez nią wykorzystana $\mathrm{w}$ trakcie $\mathrm{w}$ pracy $\mathrm{z}$ dziewczętami, które wstępowały do zgromadzenia, którego Okońska była założycielką. W sposób szczególny przydawała się jej wiedza psychologiczna, pedagogiczna i teologiczna. Dzięki niej mogła poznać potrzeby psychiczne i psychologiczne swoich podopiecznych, przez co mogła dotrzeć do ich „serc i rozumu”. Związki ze środowiskiem akademickim i znanymi profesorami, wykładowcami mogły wpłynąć na jej umiejętności interpersonalne, które wykorzystała do kontaktów z ludźmi, umiejętnie potrafiła z nimi rozmawiać. W trakcie studiów wykrystalizowały się jej idee na temat „miasta dziewcząt", „ósemki”. Możliwe,

\footnotetext{
${ }^{30}$ Tamże.

${ }^{31}$ Tamże. Na zachowanej dokumentacji nie odnotowano informacji, które wykłady i zajęcia nie zostały zaliczone przez Marię Okońską.
} 
iż dzięki studiom $w$ trakcie tajnych kompletów, wiele zagadnień związanych $\mathrm{z}$ tą ideą stawało się dla niej bardziej zrozumiałych i potrzebnych do urzeczywistnienia.

Zachowane archiwalia w uczelnianych archiwach stanowią idealne uzupełnienie życiorysu Okońskiej. Poszerzają go o materiały archiwalne w postaci zachowanych kart wpisowych, życiorysów, kart rejestracyjnych na dany rok akademicki. Obrazują postępy w nauce czy uzyskanie tytułu magistra filozofii w zakresie pedagogiki. Ponadto archiwalia stanowią idealne źródło wiedzy na temat organizacji kształcenia w czasie okupacji i w okresie krótko po niej. Należy zaznaczyć, iż dzięki materiałom archiwalnym poznajemy programy studiów, nazwy przedmiotów oraz tytuły i stopnie naukowe jej nauczycieli, których dzięki nauce poznała.

Podsumowując edukację akademicką Marii Okońskiej, należy podkreślić, iż w latach 1941-1952 była słuchaczką uczelni, które działały w czasie drugiej wojny światowej w konspiracji i bezpośrednio po niej wznawiały swoją działalność. Dla przypomnienia należy zaznaczyć, iż studiowała na: Tajnym Uniwersytecie Warszawskim (1940-1943), kierunek polonistyka; Tajnym Uniwersytecie Ziem Zachodnich (1940-1943), kierunek psychologia i pedagogika; Uniwersytecie Poznańskim (1945-1946), kierunek pedagogika; Uniwersytecie Warszawskim (1945-1946), kierunek polonistyka; Katolickim Uniwersytecie Lubelskim (1946-1949), kierunek filozofia oraz Uniwersytecie Warszawskim (1949-1952), kierunek teologia.

Uważam, iż temat edukacji akademickiej Marii Okońskiej można by poszerzyć o kolejne badania m.in. o jej edukację szkolną i ogólnokształcącą, o ile zachowały się tego typu materiały archiwalne dotyczące tej kwestii. Należało by uzupełnić kwerendy o prześledzenie edukacji akademickiej kobiet, członkiń Instytutu, które były jej najbliższymi współpracowniczkami.

Reasumując, przedstawiona $\mathrm{w}$ artykule edukacja akademicka Marii Okońskiej w świetle archiwaliów ukazuje nie tylko proces zdobycia przez nią wyższego wykształcenia, ale też proces kształcenia w czasie tajnych kompletów w okresie drugiej wojny światowej. Ponadto zachowane archiwalia prezentują również proces odbudowy kształcenia akademickiego po drugiej wojnie światowej na uczelniach, których była słuchaczką.

\section{Bibliografia}

\section{Źródła archiwalne}

Teczka studencka Marii Okońskiej, Archiwum Uniwersytetu im. Adama Mickiewicza w Poznaniu, sygnatura 144/1054.

Teczka studencka Marii Okońskiej, Archiwum Uniwersytetu Warszawskiego, sygnatura WTK 3142. 
Teczka studencka Marii Okońskiej, Archiwum Katolickiego Uniwersytetu Lubelskiego, sygnatura F 7914.

Teczka pracownicza Marii Okońskiej, Archiwum Katolickiego Uniwersytetu Lubelskiego, sygnatura A-161.

\section{Źródła drukowane}

Okońska M., Przez Maryję wszystko dla Boga. Wspomnienia 1920-1948, Warszawa 2008.

Okońska M., Stefan Kardynat Wyszyński na co dzień. Świadectwo, Warszawa 2001.

Okońska M., Wspomnienie z Powstania Warszawskiego, Warszawa 2004.

Okońska M., Z misją do Komańczy, Warszawa 2006.

Wyszyński S., A była tam matka..., oprac. M. Okońska, M. Plaskacz, A. Rastawicka, Warszawa 2001.

Wyszyński S., Kromka chleba. Wybór myśli i aforyzmów z kazań, przemówień, rozważań, oprac. M. Okońska, M. Plaskacz, ks. Z. Peszkowski, A. Rastawiecka, Warszawa 2001.

Wyszyński S., Miłość na co dzień. Rozważania, oprac. M. Okońska, M. Plaskacz, A. Rastawicka, Warszawa 2001.

Wyszyński S., Nie gaście Ducha ojca Maksymiliana. Wybór przemówień i listów, oprac. M. Okońska, M. Plaskacz, A. Rastawicka, Niepokalanów 1996.

Wyszyński S., Zapiski milenijne. Wybór z dziennika "Pro memoria" z lat 1965-1967, oprac. M. Okońska, M. Plaskacz, A. Rastawicka, Warszawa 2001.

\section{Opracowania}

Czaczkowska E.K., Kardynat Wyszyński, Warszawa 2009.

Raina P., Jasnogórskie śluby Narodu Polskiego 1656-1956-1966, Warszawa 2006.

\section{Strony internetowe}

Brzezińska M., Maria Okońska - córka duchowa prymasa Wyszyńskiego, https://kobieta.wp.pl/ maria-okonska-corka-duchowa-prymasa-wyszynskiego-5982317966279809a (dostęp 4 lipca 2018 r.).

Polak-Pałkiewicz E., Jest Bóg i czegóż ci więcej... (śp. Maria Okońska 1920-2013), http:/ /ewapolak-palkiewicz.pl/jest-bog-i-czegoz-ci-wiecej-sp-maria-okonska-1920-2013/ (dostęp 4 lipca 2018 r.).

Założyciele, http://www.instytutwyszynskiego.pl/index.php/it/historia?showall=1\&limitstart= (dostęp 4 lipca 2018 r.). 
Piotr Józefiak

\title{
Edukacja akademicka Marii Okońskiej w świetle archiwaliów
}

\section{Streszczenie}

Artykuł przedstawia edukację akademicką Marii Okońskiej, założycielki Instytutu Prymasa Wyszyńskiego i jego najbliższej współpracowniczki. Ukazana została jej krótka biografia prezentująca jej dokonania i zasługi. W tekście została przeprowadzona analiza jej drogi do uzyskania wyższego wykształcenia w oparciu o zachowane materiały archiwalne stanowiące dokumentację przebiegu studiów. W tekście omówiono jej edukację w czasie okupacji i w okresie krótko powojennym.

Słowa kluczowe: Okońska Maria, Wyszyński Stefan, edukacja akademicka, Tajny Uniwersytet Warszawski, Tajny Uniwersytet Ziem Zachodnich, Uniwersytet Poznański, Uniwersytet Warszawski, Katolicki Uniwersytet Lubelski, akta studenckie, dokumentacja przebiegu studiów

\section{Academic education of Maria Okońska in the light of archival materials}

\begin{abstract}
The article presents the academic education of Maria Okońska, the closest associate of primate Stefan Wyszyński and the founder of the Stefan Wyszyński Institute. It features a short biography with her most notable achievements, as well as an analysis of her journey towards completing her degree, based on the available archival materials documenting the course of her academic experience. It also includes the description of her education during the period of occupation and shortly after the war.
\end{abstract}

Key words: Okońska Maria, Wyszyński Stefan, academic education, Underground Warsaw University, Western Lands Underground University, Poznań University, Warsaw University, Catholic University of Lublin, student files, university records 